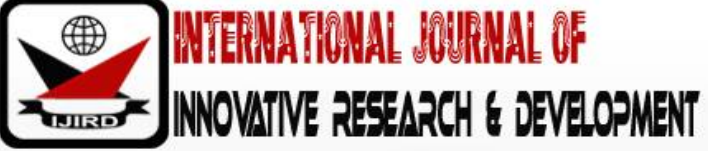

ISSN 2278 - 0211 (Online)

\section{Mechanical Properties of as-Cast A232 Aluminium Alloy}

\begin{tabular}{c}
\hline Mbudai Dzugu Yohanna \\
Principal Lecturer, Department of Mechanical engineering, Adamawa state polytechnic, Nigeria \\
Danladi Ismaila \\
Lecturer, Department of Mechanical Engineering, Adamawa State Polytechnic, Nigeria \\
\hline
\end{tabular}

\begin{abstract}
:
The A232 Aluminium alloy was produced sing a dry sand mould castings at the foundry shop of department of metallurgical and material engineering Ahmadu Bello University Zaria(ABU).The alloy was cast into cylindrical bars of $12,14,16,18$ and $20 \mathrm{~mm}$ diameterand $300 \mathrm{~mm}$ by length each. The as-cast bars were cut and machined to standard tensile impact and hardness test specimens. The tensile strengths, hardness values and impact test of the various cast samples were determined. It was found that both tensile and impact strength properties decreases as the section size increases. While the hardness slightly increases with the section thickness. The overall result showed that the moulding technique and section thickness had influence on the mechanical properties of the cast metal.
\end{abstract}

Keyword: Tensile strength, impact toughness and hardness number

\section{Introduction}

For over fifty years, Aluminum has been a tonnage metal, second only to suet as a major factor in the metal industry. The growth has been based on the characteristics such as light weight, non-rusting properties, reasonably good strength and ductility, easy fabrication, modem metallurgical control of structure and properties, and favorable electronics (Henkeletal,2002).

A luminium alloys are the largest proportion of non-ferrous alloys used in the production of automobile components, building and construction containers and packaging, marine, aviation, aerospace and electrical industries (Yaro, et al). They are highly reflective to radian energy, visible light, heat and electromagnet waves apart from possessing excellent machinability and good reserve to scratching (Yaro et al,2006).

Historically, the development of casting practices for aluminum and its alloys is a relatively recent accomplishment. Aluminum alloys were n o t available in any substantial quantity for casting purpose until long after thediscovery in 1886 of the electrolytic process of reduction of aluminum oxide by Charles Maitin Hall in the United States and Pout Haroolt in France (Richard Carl and Philip 1962). Although Halls invention provide aluminum at a great reduced cost, the full value of aluminum as a casting material was not established until alloys suitable for foundry process were developed (Richard et at 1962). Since about 1915, a combination of circumstances-gradually decreasing cost, the expansion of air transportation, development of specific casting alloys improved properties. And the impetus provided by the two world wars has resulted inan ever-increasing useofaluminum casting (Richard etat 1962).

Aluminum is one of the few metals that can be cast by all the processes use in casting. These processes in decreasing order of amount of aluminium casting are: die casting, permanent mould casting, sand casting (green and dry sand), plaster casting, investment castingand continuous casting (Rundman, 2007)

However, sandcasting is the mostversatilemethodforcastingaluminum alloys providing the greatest latitude for size, shape and alloy cast, (Madugu Abdulwahab 2007; Ekey 1968).

Because of the low pouring temperature and specific gravity of aluminum alloys moulds are less affected by heat than in the case of iron and steel. Consequently, excellent surface finish and dimensional accuracy may be obtaining even in large sand castings. The minimum section thickness for sand casting aluminum casting is $\frac{1}{8} \mathrm{in}, \frac{5}{32}$ in, and $\frac{3}{16}$ in respectively (Richardetal 1962).

Aluminum alloys may be cast in dry sand mould, green sand mould and loam-sand mould. However, the cooling rateof these sand moulding processes in relation to the variation in section thickness and the sand moulding techniques is quite different and thus influences the structures and properties of the castings. Due to the high application of Aluminum based alloys in aerospace industries and other light industries application, the need to develop a sand casting with optimum mechanical properties is very essential. 


\section{Methodology}

\subsection{Materials}

Pure Aluminum scrap used for this investigation was obtained from NOCACO Nigeria limited, Kaduna, with 99.9\% purity. While the magnesium and Nickel were obtained from chemical laboratory in Zaria, Kaduna state. The ligand $(50 \% \mathrm{Al}-50 \% \mathrm{Cu})$ used was obtained from NMDC Jos. Cylindrical steel pipes of various diameters $(12-20 \mathrm{~mm})$ obtained from Zaria main markets were used as patterns. The composition of the Aluminum produced is given in the table below.

\begin{tabular}{|c|c|}
\hline Element & \% Composition \\
\hline $\mathrm{Cu}$ & $3 \%$ \\
\hline $\mathrm{Ni}$ & $2.5 \%$ \\
\hline $\mathrm{Mg}$ & $2 \%$ \\
\hline $\mathrm{Al}$ & $92.5 \%$ \\
\hline
\end{tabular}

Table 1: Composition of as-cast (A232) Aluminium a ll oy

\subsection{Apparatus and Equipment}

The following apparatus and equipment were used for the investigation; a $2 \mathrm{Kg}$ charged-fired pit furnace, Mould assembly, Pattern of cylindrical steel pipes of various diameter, Lathe machine, Grit papers of different grades (60, 120, 180, 240, 320, and 600), 2\% nital solution (etchant), Polishing cloth, Hand gloves, Tensile test machine, Impact test machine, Rockwell hardness test machine, Polishing machine etc.

\subsection{Methods}

In the present investigation, various casting of A232 Aluminum alloy samples was produced using different moulding techniques and varying sectionthickness. The mechanical propertiesofallthesampleswere carried out.

\subsection{Sand and Mould Preparation}

The sand that was used for the production of mould was obtained from foundry workshop of metallurgical and materials department ABU Zaria. Dry sand castings technique was used in this research work. The sand as received was mixed with water inappropriate proportion. The combination of the water and sand was mixed thoroughly until the required plasticity was obtained Cylindrical steel pipes were used as patterns. The prepared sand was then rammed round the pattern of different diameter ranging from $12-20 \mathrm{~mm}$ diameter and $300 \mathrm{~mm}$ length each with due consideration of allowance for shrinkage. It was left for six days todry.

\subsection{Charge Composition Calculation}

The charge composition and weight per heat of material charge into the crucible was determined asfollow:

Volume of mould:

The volume of the fabricated mould were calculated using the relationship given below (with consideration of losses);

volume of cylinder $=\pi r^{2} h-------1$

Where: $\pi=3.142$

$$
\begin{aligned}
& \mathrm{D}=20 \mathrm{~mm}=2 \mathrm{~cm}, \mathrm{r}=1 \mathrm{~cm} \\
& \mathrm{~h}=300 \mathrm{~mm}=30 \mathrm{~cm}
\end{aligned}
$$

volume $=3.142 \times 1 \times 1 \times 30$

$$
=94.26 \mathrm{~cm}^{3}
$$

Which is also the volume of the mould.

Density of Aluminium alloy

The density of Aluminium $\left(2.7 \mathrm{~g} / \mathrm{cm}^{3}\right)$ was used since it is the major element (metal) in the alloy.

Mass of the casting

The approximate mass of the casting per mould was determined as shown below:

Density $=$ mass $/$ volume

Mass $=$ density $\times$ volume

$$
\begin{aligned}
& =2.7 \times 94.26 \\
& =254.502 \mathrm{~g}
\end{aligned}
$$

Calculation of weight percentage:

The calculation of the percentage weight of charge material $(92.5 \% \mathrm{AL}, 3 \% \mathrm{Cu}, 2.5 \% \mathrm{Ni}$, and $2.5 \% \mathrm{Mg})$ was done in the following sequence:

Total weight of metal required $=254.502 \mathrm{~g}$

Weight of $\mathrm{Cu}=\left(\frac{3}{100} \times 254.502\right)=7.64 \mathrm{~g} / \mathrm{bar}$

Weight of $\mathrm{Ni}=\left(\frac{2.5}{100} \times 254.502\right)=6.37 \mathrm{~g} / \mathrm{bar}$

Weight of $\mathrm{Mg}=\left(\frac{2}{100} \times 254.502\right)=5.1 \mathrm{~g} / \mathrm{bar}$

Weight of $\mathrm{Al}=\left(\frac{92.5}{100} \times 254.502\right)$

$=235.41 \mathrm{~g} / \mathrm{bar}$ 


\subsection{Melting and Casting}

The melting of the alloy was carried out in a charcoal fired crucible furnace. Aluminum scraps was into smaller sizes for the convenience in weighting and ease of charging into the crucible (Danladi et al 2016). The $92.5 \% \mathrm{Al}, 3 \% \mathrm{Cu}$, $2.5^{\circ} \mathrm{Ni}$ and $2 \% \mathrm{Mg}$ was measured totaled approximately $1.2 \mathrm{Kg}$ capacity and then charged into the crucible. The ligand $(50 \% \mathrm{Al}-50 \% \mathrm{Cu})$ was added when the aluminum had melted, followed by Nickel and magnesium. With the charged in the crucible, the material was heated up to $690^{\circ} \mathrm{C}$ in order to have uniform liquid state and to give consideration for heat loss during pouring of the melt. Upon removal of slag from the top of the liquid melt, the molten alloy was carefully poured into the already prepared moulds. Cooling took about 30 minutes before the sand was broken down to recover the cast alloy of $12 \mathrm{~mm}, 14 \mathrm{~mm}, 16 \mathrm{~mm}, 18 \mathrm{~mm}$, and $20 \mathrm{~mm}$ diameter and $300 \mathrm{~mm}$ length each. The Same procedures were repeatedforotherbatches.

\subsection{Sample Preparation}

The cast samples were machined at the mechanical engineering workshop ABU, Zaria. The sample for tensile, impact and hardness tests were cut and machined to standard shapes and dimension as specified by the ASTM standard.

\section{Mechanical Property Testing}

\subsection{Determination of Tensile Strength}

The tensile strength of themachined specimens was determined using tensile test machine. The test sample were machined to the ASTM standard with original diameter of $12.5 \mathrm{~mm}$ and gauge length of $17 \mathrm{~mm}$ (Khanna, 2002). The test was carried out by marking the specimen gauge length with prick punch marks and measuring the cross-sectional area of the reduced part. The specimens were then locked securely in the grips of the upper and lower cross beams of the testing machine. A small load was initially applied to seat the specimen in the grips and then the load was increased until failure occurred. Then theload and elongation atfailure were read and recorded.

\subsection{Hardness Value Determination}

The values for the hardness were determine using the Rockwell hardness tester on B, F, C scale with $5 \mathrm{~mm}$ ball indenter and 101.2HRB was used as the standard block. The marking surface of the indented, plunger rod and test sample were thoroughly cleaned by removing dirt, scratches oil and calibration of the testing machine was doneusingthestandard block.

The samples were placed on anvils, which act as a support for the test samples. A minor load of $10 \mathrm{Kg}$ was first applied to the sample in a controlled manner without inducing impact or vibration to seat the specimen and zero datum position was established, and then the major load $100 \mathrm{Kg}$ was then applied. The reading was taken when the large pointer came to rest or had slowed appreciably and allowed for up to two seconds. The Road was then removed by returning the crank handle to the latched position and the hardness value was read directly from the semi-automatic digital scale. Three reading were taken for each sample with the average value taken as the hardness valueforasample.

\subsection{Impact Strength Determination}

Impact test were conducted using Avery Denison testing machinewith impact energies ranging from 0 to $300 \mathrm{~g}$. The mass of the hammer was $22 \mathrm{Kg}$ and the striking velocity $3.5 \mathrm{~m} / \mathrm{sec}$. Charpy impact test was conducted on notchedspeimn before the test specimen was mounted on the machine, thependulum was released to zero the scale. The test specimen was supported as a beam in a horizontal position in a vice and loaded behind the $V$-notch by the impact of a freely heavy swinging pendulum. The value of the angle through which the pendulum swing before the test specimen was broken corresponded with the value of the energy absorbed in breaking the sample and this was read from thecalibratedscaleonthemachine.

\section{Results and Discussion}

4.1. Results this section.

The experimental results of A232 Aluminium alloys produced using dry-sand moulding techniques are contained in

The results of the mechanical properties against the cast section thickness are presented as showed in figures 4.1, 4.2 and 4.3; 




Figure 1: Variation of Tensile Strength with Cast SampleSize of A232 Aluminium Alloy Produced in Dry Sand Mould

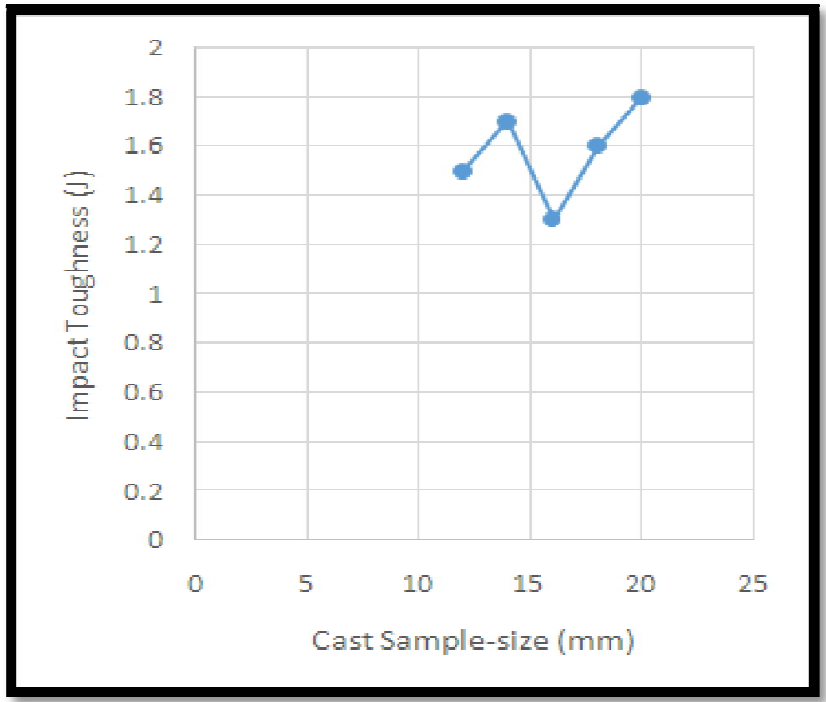

Figure 2:Variation of Impact Toughness with Cast SampleSize of A232 Aluminium Alloy Produced In Dry Sand Mould

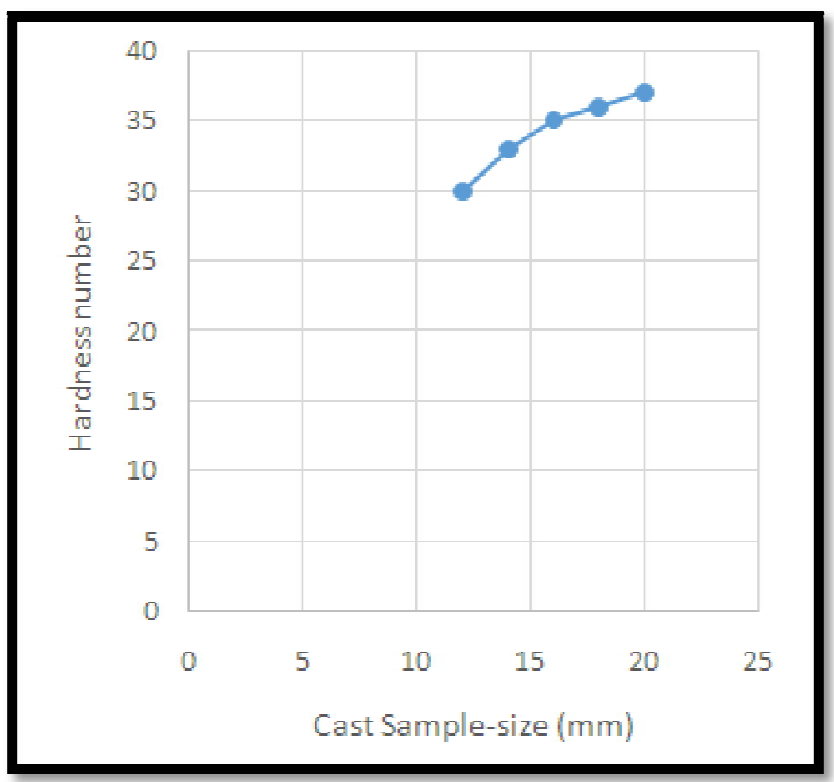

Figure 3: Variation of Hardness with Cast Sample-Size of A232 Aluminium Alloy Produced In Dry Sand Mould 


\section{Discussion}

Considering the utmost utility of material testing to engineers concerned with the design of structures in order to ensure their reliability in service, mechanical properties of material are widely used to provide basic design information and an acceptance test for the specification of materials (Dieter, 1988). Therefore, the understanding of the properties of material is highly essential (khanna, 2002).

From the results of the mechanical property tests carried out on the casts produced, it can be shown that the mould and sample section thickness have effects on the properties of the A232 aluminium alloy. The detail is discussed below;

Figures 4.1 and 4.2 shows the tensile and impact strengths of A232 aluminium alloy casting produced in different moulds and at varying section thicknesses. It was found that both tensile and impact strength properties decreased as the section size increased.

Figure 3 shows the results of hardness tests of A232 aluminium alloy produced at varying sample-size in dry sand moulds. The result showed that the hardness properties of A232 alloy casting slightly increased as the section thicknesses increased from $12 \mathrm{~mm}-20 \mathrm{~mm}$ diameter.

\section{Conclusions}

Based on the results obtained from this investigation, it was found that the rate of cooling of the sample with variation of section thickness is quite different. However, the following conclusions can also be drawn;

- Both the tensile and impact strength properties of A232 aluminium casting produced dry sand mould decreased as the section thickness of cast samples increased.

- The hardness properties of A232 aluminium alloys produced slightly increased as the size of the cast samples increased.

- The overall result showed that the moulding techniques and section thickness had influence on the mechanical properties of the cast metal.

\section{References}

i. Abdulwahab, M. Aponbiede, O. Balogun, and Bello, K.A (2006). " Comparative study on the mechanical properties fluidity and microstructure of AI -Mg Alloys Journal of Engineering science and technology volume L. No 1. Pp102106.

ii. American Society of Metal (ASM): Handbook, S Edition. 1981, pp26-56 Kempster M.H. (1979): Material for Engineers. Biddles ltd, Guildford and king lynn publisher. Britain. Pp 137-186

iii. Beeky P. R(1972); "Foundry Technology". Butterworths Publishers London, pp57-76.

iv. Danladi, I. (2016) The Effect of Different Moulding Techniques Section Thickness on Mechanical Properties of as Cast A142 Aluminium Alloy, M. Alim (Ed), Proceedings on Unlocking Sub-Sahara African Potentials for Sustainable Development in the 21st Century (pp 59-72) by Nightingale Publications and Research International.

v. Geoge E Dieter (1988): "Mechanical Metallurgy". Mc Graw-Hill Book Company. pp1-476.

vi. Harper 1.D (1988): "small scale foundries for developing countries." Birmingham publisher, UK pp1-38

vii. Henkel and pense (2002): structure and properties of engineering Materials.edition Mc Graw-Hill publishers, America. Pp-358

viii. Jacob J.A (1985): “Engineering material technology" Eagle wood diffs, New Jersey, USA. Pp 217-218.

ix. Jain P. L (2003): "principle of foundry technology" 4th Edition, tata Mcgraw-Hill publisher Khanna O. P (2002): "material and metallurgy". Dhanpat rai publication ltd pp1-49

x. Madugu. I.A and Abdulwahab M. (2006); "the effect of chromium of the mechanical properties of AL-Si-Fe alloy Journac of Research in Engineering. Vol. 3 No 4.

xi. Prentice-Hall Inc. Engie wood diff, NJ $(1961,1909)$. " Manufacturing processes and materials for Engineering." 2n Edition pp 29-189.

xii. $\quad$ Raymond a. higgin (1970): “Engineering metallurgy" 2n Edition, Edward Arnold publisher. Pp 36-110

xiii. Richard W. Heines Can. R. Lopes. c. Rosenthal (1967); "Principles of metal casting”. Mc Graw Hill. Inc. Publishers. pp1-684.

xiv. Rundman K. B (2002): Metal casting handbook Department of Materials science and Engineering Michigan Technology University.

xv. Yaro S.A. Aigbodion, V. S (2002): "the effect of copper on the mechanical properties of $\mathrm{Al}-\mathrm{Si}-\mathrm{Fe}$ Alloy" International Research Joumal in Engineering, science and Technology (IREJEST), vol 3. No. 2,2006. 